\title{
ETNOBOTANI RUMAH ADAT ETNIS DAWAN DI KABUPATEN TIMOR TENGAH UTARA
}

\section{(Ethnobotany of Traditional House of Dawan Ethnicity in North Central-Timor Regency)}

\author{
EMILIA JULIYANTI BRIA*) DAN REMIGIUS BINSASI \\ Program Studi Biologi, Fakultas Pertanian, Universitas Timor, Jalan Km. 09, Kefamenanu, Nusa Tenggara Timur, \\ Indonesia 85616
}

*Email: emiliajuliyanti@gmail.com

Diterima 18 November 2019 / Disetujui 20 Maret 2020

\begin{abstract}
Traditional house is one of the local wisdoms passed down from ancestors to their descendants in a community. The study aims to understand the diversity of plant species used as building materials for traditional houses of ethnic Dawan in North Central-Timor Regency. The samples were three traditional houses from different areas, namely Tunbaba, Fafinesu, and Tamkesi traditional house. The techniques used are interviews, observation and documentation. This study used the ethnobotany and ethnoecological approach. The results showed that 15 species of plants used as building materials for traditional houses, consists of wood, rope and roof categories. Plant species that have the highest important value index from three samples of traditional houses are (1) red wood (Pterocarpus indicus Willd) 14.64, 112.14, and 57.70 respectively, (2) trengguli (Cassia fistula L.) 105.44, 13.52, and 50.06 respectively. Uneven distribution of plant species in each region shows that the influence of abiotic environmental factors and human activities are greatly influence the existence of plants in terms of preservation.
\end{abstract}

Keywords: Building Material, Local wisdom, Traditional house

\section{ABSTRAK}

Rumah tradisional merupakan salah satu kearifan lokal yang diwariskan dari para leluhur ke keturunannya dalam suatu komunitas masyarakat. Penelitian bertujuan untuk memahami keanekaragaman dan ketersediaan spesies tumbuhan yang digunakan sebagai bahan bangunan rumah tradisional etnis Dawan dan pemanfaatannya oleh masyarakat setempat. Jumlah sampel sebanyak tiga rumah adat dari wilayah yang berbeda yakni rumah adat Tunbaba, Fafinesu, dan Tamkesi. Teknik yang digunakan dalam pengumpulan data adalah wawancara, observasi dan dokumentasi. Pendekatan yang digunakan adalah pendekatan etnobotani dan etnoekologi. Hasil penelitian menunjukkan bahwa 15 spesies tumbuhan yang digunakan sebagai bahan bangunan rumah adat tradisional terdiri atas kategori kayu, tali, dan atap. Spesies tumbuhan yang memiliki indeks nilai penting tertinggi dari ketiga sampel rumah adat adalah kayu merah (Pterocarpus indicus Willd) berturut-turut 14,64; 112,14; dan 57,70 dan trengguli (Cassia fistula L.) berturut-turut 105,44; 13,52; dan 50,06. Distribusi spesies tumbuhan tidak merata di setiap wilayah menunjukkan adanya pengaruh faktor lingkungan abiotik dan aktivitas manusia yang sangat memengaruhi keberadaan tumbuhan dalam hal pelestarian.

Kata kunci: bahan bangunan, kearifan lokal, rumah tradisional

\section{PENDAHULUAN}

Etnis Dawan merupakan salah satu etnis besar dari Suku Timor yang mendiami pulau Timor. Masyarakat di Kabupaten Timor Tengah Utara hampir semuanya merupakan Etnis Dawan yang biasa dikenal sebagai orang Dawan atau atoin meto. Etnis Dawan di wilayah ini terdiri atas tiga suku besar yakni suku Biboki, Insana dan Miomaffo, yang biasa disingkat menjadi BiInMaffo. Selain dialek dan logat dalam bertutur kata serta motif kain tenun, masyarakat etnis ini juga dapat dibedakan berdasarkan bangunan rumah tradisionalnya. Soedigdo (2010) menyatakan bahwa rumah tradisional merupakan bangunan yang memiliki kegunaan, fungsi sosial dan arti budaya dibalik corak atau gaya bangunannya. Rumah tradisional suatu masyarakat merupakan lambang cara hidup, ekonomi dan beberapa aspek lainnya dalam kehidupan masyarakat.
Rumah tradisional etnis dawan terdiri atas rumah adat (Uem/ume Leu), rumah tinggal yang bentuknya bulat (Uem/ume Kbubu) dan rumah serambi (Lopo). Karwur et al. (2016) dalam penelitiannya menyatakan bahwa Ume Kbubu/rumah tinggal merupakan pusat aktivitas utama keluarga yang diasosiasikan dengan peranan perempuan dan sikap kerendahan hati. Selanjutnya, Lopo yang berada di depan setiap rumah dikaitkan dengan peranan laki - laki dan lambang perlindungan serta pengayoman terhadap penghuninya. Rumah adat atau Uem Leu merupakan pusat segala aspek kehidupan suatu masyarakat. Di rumah adat inilah tersimpan segala macam artefak peninggalan leluhur yang diwariskan dan juga merupakan pusat segala proses ritual adat masyarakat.

Rumah tradisional etnis Dawan, umumnya menggunakan bahan-bahan tradisional dan berasal dari alam. Zulharman dan Aryanti (2016) mengungkapkan bahwa pengetahuan lokal masyarakat dalam mencari 
bahan bangunan, rumah adat dan kerajinan merupakan suatu bentuk kearifan karena pemanfaatannya sesuai dengan kaidah ekologi. Irsyad et al. (2013) berhasil mengidentifikasi 29 jenis tumbuhan yang digunakan sebagai bahan bangunan antara lain, jati (Tectona grandis L.f), nangka (Artocarpus heterophyllus Lamk.), jamblang (Syzygium cumini (L.) Skeels), johar (Senna siamea (Lamk.) Irwin et. Barneby), mimba (Azadirahcta indica (Blume) Miq.), mahoni (Swietenia mahagoni (L) Jacq.), sonokeling (Dalbergia latifolia Roxb.), meh (Samanea saman Merr.), dan sengon (Paraserianthes falcataria (L) I.C. Nielsen). Selanjutnya, Atok et al. (2010) berhasil mengungkapkan tumbuhan yang digunakan sebagai bahan bangunan suku Bunaq di Nusa Tenggara Timur antara lain tal (Eucalyptus urophylla S.T. Blake), pie (Eucalyptus alba Reinw ex. Blume), hur (Casuarinas junghuniana Miq.), siba leboq (Syzygium polyanthum (Wight) Walpers), alang-alang (Imperata cylindrica (L) Raeusch), kelapa (Cocos nucifera L.), dan bambu pagar (Bambusa multiplex (Lour.) Raeusch. ex Schult. \& Schult f.).

Seiring dengan perubahan zaman dan perkembangan teknologi saat ini, bahan tradisional sudah digantikan dengan bahan bangunan modern karena mudah didapatkan dan mudah dalam pelaksanaanya (Fanggidae 2014). Di lain pihak, bahan-bahan tumbuhan lokal semakin sulit diperoleh. Hal ini disebabkan habitat tumbuhan bahan bangunan sudah digunakan untuk membuka lahan pertanian, daerah irigasi dan daerah pemukiman. Lanoeroe et al. (2005) mengungkapkan bahwa kemajuan ilmu pengetahuan dan teknologi telah banyak mempengaruhi peradaban suku bangsa di dunia. Perkembangan ini juga mengancam kelestarian pengetahuan tradisional yang dimiliki masyarakat etnis Dawan dalam proses pembuatan rumah tradisional.

Etnobotani merupakan disiplin ilmu yang memiliki keterpaduan/hubungan atau interaksi antara tumbuhan tertentu dengan kelompok masyarakat. Etnobotani menjelaskan tentang pengetahuan masyarakat tradisional terhadap penggunaan tumbuhan dalam menunjang kehidupannya seperti untuk kepentingan pangan, obat, bahan bangunan, upacara adat, budaya, bahan pewarna dan kepercayaan yang ada dalam komunitas masyarakat (Ahmed 2010). Prinsip dasar ekologi dalam penelitian etnobotani menjadi bagian penting dalam konteks pengungkapan keanekaragaman hayati tumbuhan bagi kelangsungan hidup manusia. Jenis-jenis tumbuhan baik liar maupun budidaya, merupakan sumber seluruh sumber daya biologi, tempat manusia mendapatkan seluruh kebutuhan hidup, baik untuk kebutuhan pangan, kesehatan maupun produk industri. Penelitian etnobotani dilakukan dalam kaitannya dengan konservasi (pemanfaatan berkelanjutan) yang menjadi bagian prinsip hidup hakiki karena mampu menghasilkan manfaat ekonomi dan pembangunan bangsa (national building) (Walujo 2011). Penelitian ini bertujuan untuk memahami keanekaragaman dan ketersediaan spesies tumbuhan yang digunakan sebagai bahan bangunan rumah tradisional etnis Dawan di Kabupaten Timor Tengah Utara.

\section{METODE PENELITIAN}

Penelitian dilakukan pada April sampai Agustus 2019 dengan pendekatan survey eksploratif yang dimulai dari tahap observasi di lapangan. Pengambilan data dilakukan pada tiga lokasi yang ditentukan yakni Kecamatan Miomaffo Timur, Kecamatan Insana Fafinesu, dan Kecamatan Biboki Selatan (Gambar 1). Penentuan lokasi ini mengacu pada tiga suku besar di wilayah Timor Tengah Utara.

Pengumpulan data dilakukan dengan teknik triangulasi data dengan metode penelitian deskriptif kualitatif (Jumari et al. 2012; Awalia et al. 2014) dengan sedikit modifikasi, yang terdiri atas 1) wawancara bebas (open ended) dan wawancara semi terstruktrur (Purwanto 2007), observasi partisipatif (Martin 1995), dan dokumentasi.

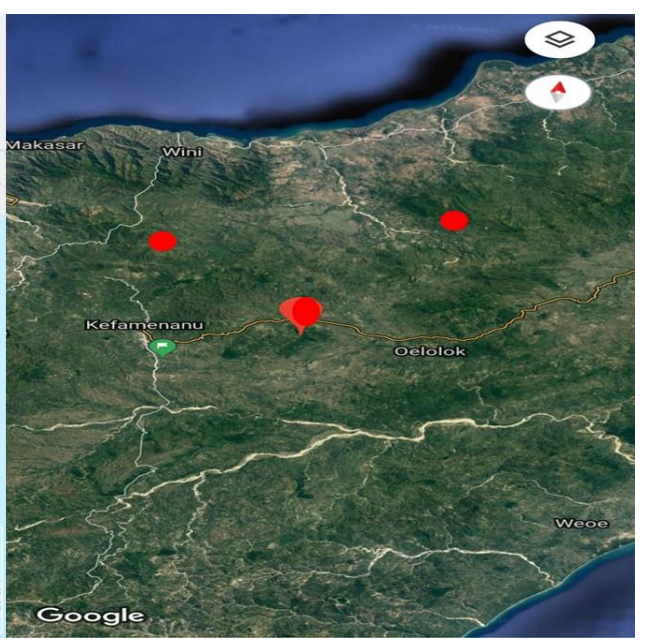

Gambar 1 Lokasi penelitian, Kabupaten Timor Tengah Utara, Provinsi Nusa Tenggara Timur, Indonesia 
Penentuan informan untuk wawancara ditentukan secara terpilih (purposive sampling) dengan teknik snowball. Peneliti menemui informan utama (tokoh adat) yang mengetahui informan lainnya yang dapat memberikan data yang dibutuhkan dalam penelitian ini (Supiandi et al. 2019).

Adapun kriteria informan yang diwawancara adalah masyarakat yang memiliki pengetahuan dan memahami semua informasi terkait dengan tujuan peneliti dan masyarakat yang memiliki pengalaman tertentu yang berhubungan dengan tema penelitian seperti tokoh adat, penjaga rumah adat, dan masyarakat yang memiliki pengetahuan tentang keberadaan bahan bangunan di alam. Wawancara dilakukan secara semi-struktur untuk mendapatkan data berupa nama tumbuhan, bagian tumbuhan yang digunakan, kegunaan untuk rekonstruksi, dan tempat tumbuhan didapatkan (Cunningham 2001; Pramita et al. 2013). Data hasil wawancara dianalisis secara deskriptif dan disajikan dalam bentuk tabel dan juga gambar (model rumah adat 3-d / tiga dimensi).

Inventarisasi dilakukan dengan mendatangi habitat tumbuhan tersebut, kemudian dilakukan dokumentasi dengan memotret tumbuhan tersebut dan dibuat spesimen herbarium dengan mengambil sampel tanaman berupa daun, bunga, ataupun buah. Selanjutnya dilakukan identifikasi nama ilmiah yang mengacu pada Backers dan Bakhuizen (1968); Tjitrosoepomo (1988); Database pada Integrated Taxonomic Information System (ITIS); dan United State Department Agriculture (USDA) Plants Database.

Penentuan estimasi kemelimpahan spesies menggunakan metode tanpa plot/metode jarak (point center quarter method) (Nicolson 2001). Penelitian ini menggunakan enam titik sampling dalam setiap lokasi yang dikaji. Setelah itu, transek diletakkan seperti sisir (baseline di tepi) yang ditentukan sebagai titik awal baseline. Jarak antar transek adalah $10 \mathrm{~m}$. Garis ini menjadi lokasi penempatan garis transek. Setiap titik sampling terdiri atas empat kuardran dengan membuat garis tegak lurus (Gambar 2).
Parameter vegetasi yang diukur yaitu pohon. Pada setiap kuadran ditentukan satu jenis pohon yang memiliki jarak terdekat ke titik sampling, kemudian dirata-ratakan (Wiryono 2012). Untuk mengetahui kontribusi masingmasing spesies dalam komunitas tersebut, digunakan analisis indeks nilai penting (INP) yang merupakan parameter kuantitatif yang dapat dipakai untuk menyatakan tingkat dominasi (tingkat penguasaan) spesies-spesies dalam komunistas tumbuhan. Nilai penting didapat dari penggabungan nilai relatif dari parameter ekologi yaitu densitas, dominansi, dan frekuensi. Adapun perhitungan tersebut mengacu pada Kuswantoro et al. (2018) dengan menggunakan rumus sebagai berikut:

$$
\begin{aligned}
& \text { Rerata jarak }=\frac{\text { jumlah jarak }}{\text { banyaknya kuarter }} \\
& \text { Densitas absolut }=\frac{\text { Unit luasan }}{(\text { Rerata jarak })^{2}} \\
& \text { Densitas relative }(\mathrm{DR})=\frac{\text { Jumlah individu suatu jenis }}{\text { Jumlah kerapatan semua jenis }} x 100 \% \\
& \text { Frekuensi }=\frac{\text { Jumlah titik sampling dengan spesies A hadir }}{\text { Total titik sampling }} \\
& \text { Frekuensi relative }(\mathrm{FR})=\frac{\text { Jumlah frekuensi suatu jenis }}{\text { Jumlah nilai frekuensi seluruh jenis }} x 100 \% \\
& \text { Luas basal area }=\frac{1}{4} \pi x(\text { diamter })^{2} \\
& \text { Luas basal areal (LBA) relatif }=\frac{\text { Jumlah total basal area spesies A }}{\text { Jumlah total individu spesies A }} X 100 \% \\
& \mathrm{NP} \text { (nilai penting) speseis } \mathrm{A}=\mathrm{DR} \text { spesies } \mathrm{A}+\mathrm{FR} \\
& \text { spesies A + LBA } \\
& \text { relative spesies } \mathrm{A}
\end{aligned}
$$

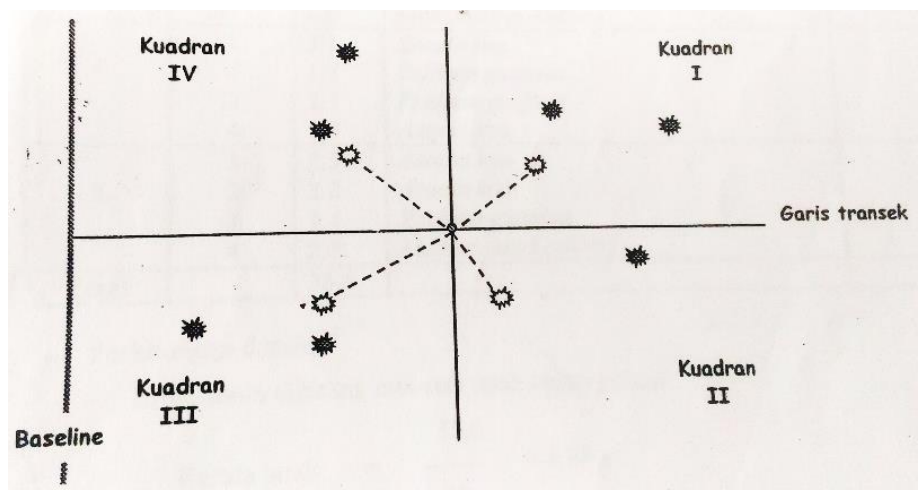

Gambar 2 Metode point centered quarter. Penempatan kuadran I-IV searah jarum jam

(Mueller-Dombois dan Ellenberg 1974). 


\section{HASIL DAN PEMBAHASAN}

\section{Rumah Adat dan Kepercayaan Etnis Dawan}

Hasil survei menunjukkan bahwa rumah adat etnis Dawan di Kabupaten Timor Tengah Utara sangat beragam bentuknya berdasarkan wilayahnya (Gambar 3). Rumah adat ini biasa disebut 'Sonaf'. Variasi yang sangat unik adalah terletak pada bentuk rumahnya. Hasil pengamatan dibuat dalam bentuk tiga dimensi (Gambar 4). Bentuk ketiga rumah adat adalah bervariasi yakni bulat dan beralaskan tanah (rumah adat Tunbaba dan Insana Fafinesu), dan persegi panggung (rumah adat Tamkesi).

Menurut tetua adat (Tunbaba dan Fafinesu), bentuk rumah adat yang bulat mencerminkan kesetaraan (licin) kepada sesama dengan tidak membeda-bedakan. Alas tanah menunjukkan rendah atau hinanya manusia di hadapan Tuhan. Selain itu, jumlah pintu juga menunjukkan perbedaan. Rumah adat Tunbaba dan Fafinesu hanya memiliki satu pintu sebagai jalan masuk keluar rumah adat. Hal ini mencerminkan kepercayaan bahwa manusia berasal dari Tuhan dan akan kembali ke Tuhan. Rumah adat Tamkesi memiliki bentuk persegi panjang dan panggung, mencerminkan martabat manusia yang lebih tinggi dibandingkan makhluk hidup lainnya. Selain itu, rumah adat Tamkesi juga memiliki dua pintu yakni pintu depan dan pintu samping. Pintu samping ini berfungsi untuk memperlancar urusan ritual dalam rumah adat atau jalur alternatif dan biasanya digunakan oleh para wanita.
Perbedaan bentuk rumah-rumah adat ini juga erat hubungannya dengan topografi wilayah. Rumah adat Tunbaba dan rumah adat Fafinesu, umumnya berada di daerah yang tanahnya rata dan padat, sedangkan daerah Tamkesi memilki topografi tanah landai berbatu kerikil besar. Namun, ketiga rumah adat tersebut umumnya terdiri atas beberapa komponen yang sama, yakni arah bangunan rumah adat, tiang utama, dinding, atap dan tiang persembahan yang terletak di depan setiap rumah adat.

Arah bangunan rumah adat selalu menghadap ke timur. Menurut para tetua adat di ketiga rumah adat, hal ini mengandung filosofi kepercayaan 'loro sa'e' (matahari terbit) dan 'loro monu' (matahari terbenam). Selanjutnya, tiang utama terletak di tengah rumah adat dan biasanya terdiri atas dua. Tiang utama ini melambangkan posisi laki-laki dan perempuan. Pada rumah adat Insana Fafinesu perbedaan tinggi kedua tiang ini sangat ekstrim, yakni tinggi tiang perempuan 3/4 dari tiang laki-laki, tetapi kedua tiang ini selalu dihubungkan oleh tiang penghubung yang horizontal. Untuk rumah adat Tamkesi, perbedaan kedua tiang hanya berbeda 3-5 $\mathrm{cm}$ dan dihubungkan dengan tiang penghubung horizontal juga (Gambar 4). Menurut para tetua adat, hal ini menggambarkan kisah penciptaan manusia, dimana manusia pertama adalah laki-laki dan perempuan berasal dari tulang rusuk laki-laki. Selain itu juga, hal ini menunjukkan kesetaraan laki-laki dan perempuan dalam suatu komunitas masyarakat yang harus terdiri atas lakilaki dan perempuan sehingga masyarakat tersebut menjadi utuh dan seimbang.

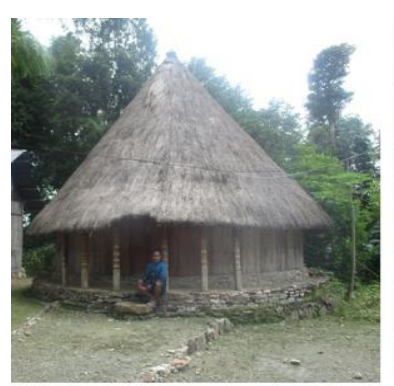

Rumah Adat Tunbaba, Kec. Miomaffo Timur

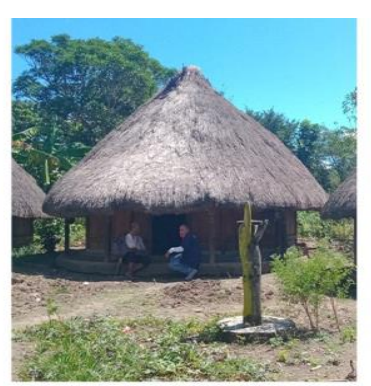

Rumah Adat Fafinesu, Kec. Insana Fafinesu

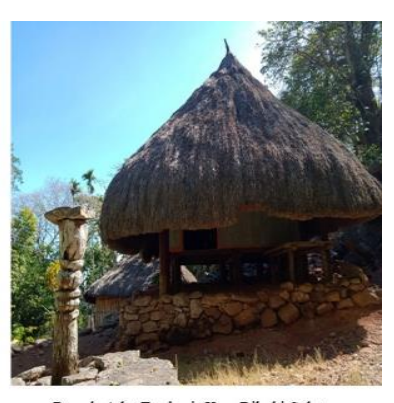

Rumah Adat Tamkesi, Kec. Biboki Selatan

Gambar 3 Variasi bentuk rumah adat Etnis Dawan di Kabupaten Timor Tengah Utara
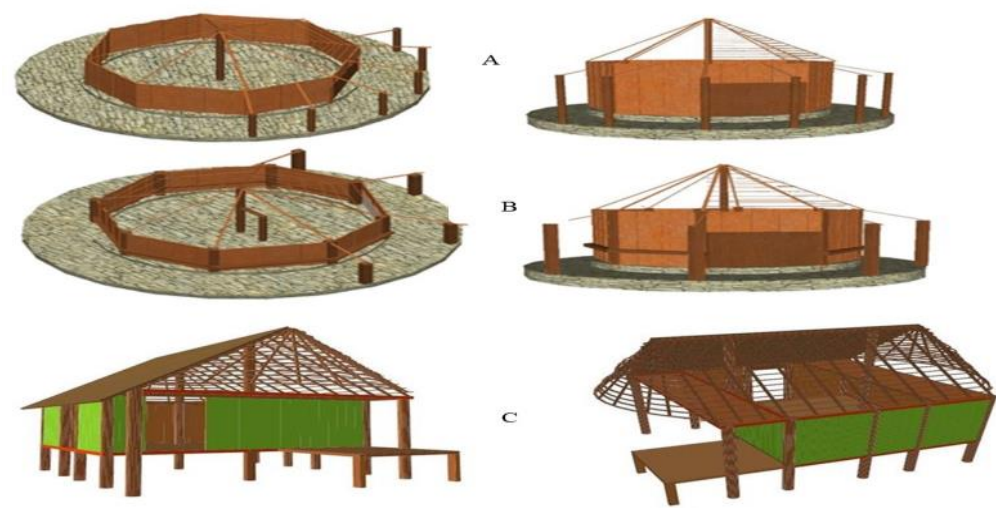

Gambar 4 Pemodelan 3-D rumah adat Etnis Dawan di Kabupaten Timor Tengah Utara. Keterangan: Rumah Adat Tunbaba (A); Rumah Adat Fafinesu (B); Rumah Adat Tamkesi (C). 


\section{Spesies Tumbuhan Bahan Bangunan Rumah Adat Etnis Dawan}

Masyarakat Etnis Dawan umumnya menggunakan bahan bangunan yang diambil dari alam (Tabel 1). Pemanfaatan tumbuhan yang digunakan juga dilakukan secara terencana dan berkelanjutan. Bahan-bahan bangunan yang digunakan untuk membuat rumah adat, langsung diperoleh dari alam. Setiap anggota masyarakat dalam rumah adat/Sonaf tersebut, memiliki kewajiban untuk menyumbangkan bahan-bahan bangunan tersebut.

Dalam proses pengambilannya, pohon-pohon yang dijadikan bahan bangunan, dipilih terlebih dahulu berdasarkan beberapa pertimbangan yakni umur pohon, besar pohon, kelurusan pohon. Seteleh pohon ditentukan, selanjutnya langsung ditebang menggunakan alat bantu.

Ketiga rumah adat tersebut menggunakan kayu matani/kayu merah (Pterocarpus indicus L.) sebagai tiang utama. Menurut informan utama (tetua adat), kualitas kayu ini sangat baik dan tidak mudah lapuk dalam jangka waktu yang lama. Hal ini mencerminkan kuat dan kokohnya keberadaan suku tersebut. Selain itu, pohon tiang utama yang akan digunakan harus berasal dari wilayah (kampung) adat tersebut. Jika pohon tersebut tidak berasal dari wilayah tersebut, harus dilakukan ritual adat dengan persembahan korban berupa hewan dengan tujuan jual-beli dan menolak segala malapetaka dari luar wilayah.
Saat ini, tiang utama rumah adat etnis Dawan sudah banyak yang digantikan dengan bahan bangunan modern. Hal ini disebabkan ketersediaan kayu matani/kayu merah yang sudah sangat jarang ditemukan.

Tiang penyangga lainnya selain menggunakan kayu merah, dapat diganti dengan kayu jenis lainnya seperti kayu jati, akasia, trengguli, trengguli wanggang, tegining ganang, dan kayu putih. Pemilihan kayu-kayu ini hanya berlandaskan kriteria kuat dan lurus tanpa adanya kepercayaan tertentu. Bagian dinding umumnya menggunakan jati dan/atau mahoni dalam bentuk papan. Jenis kayu jati, akasia, dan mahoni juga digunakan dalam pembuatan rumah adat 'Uma Lengge' Suku Sambori di Nusa Tenggara Barat (Zulharman dan Aryanti 2016).

Atap bangunan rumah adat terdiri atas bagian yang tegak menuju ke puncak dan bagian melengkung. Bagian tegak umumnya menggunakan kayu jati dan untuk bagian melengkung dapat menggunakan salah satu atau lebih yakni enau, rotan, pohon lelak, dan kulit pohon pinang. Selanjutnya, untuk mengikat alang-alang sebagai atap ke kayu lengkungan atapnya digunakan serat bambu pagar atau kayu bendoh. Selain sebagai bahan bangunan, aren dan bambu juga dapat dimanfaatkan sebagai kerajinan tangan masyarakat setempat. Hal ini dibuktikan dalam penelitian Sujarwo dan Keim (2017) yang mengungkapkan nilai guna tumbuhan Aren bagi masyarakat Bali.

Tabel 1. Spesies tumbuhan bahan bangunan rumah adat Etnis Dawan di Kabupaten Timor Tengah Utara

\begin{tabular}{|c|c|c|c|c|c|c|}
\hline No & Jenis tumbuhan & Nama Indonesia & $\begin{array}{l}\text { Nama } \\
\text { lokal }\end{array}$ & Famili & $\begin{array}{l}\text { Bagian yang } \\
\text { digunakan }\end{array}$ & Kegunaan \\
\hline 1 & $\begin{array}{l}\text { Pterocarpus indicus } \\
\text { Willd. }\end{array}$ & Kayu merah & Matani & Fabaceae & Batang & Tiang utama \\
\hline 2 & Cassia fistula L. & Trengguli & Nikis & Fabaceae & Batang & $\begin{array}{l}\text { Tiang persembahan } \\
\text { dan/atau tiang sudut }\end{array}$ \\
\hline 3 & $\begin{array}{l}\text { Swietenia mahagoni (L.) } \\
\text { Jacq }\end{array}$ & Mahoni & Mahoni & Meliaceae & Batang & Tiang penyangga \\
\hline 4 & Acacia mangium Willd. & Akasia & Akasia & Fabaceae & Batang & Dinding \\
\hline 5 & Cassia javanica $\mathrm{L}$. & $\begin{array}{l}\text { Trengguli } \\
\text { wanggang }\end{array}$ & Buni & Fabaceae & Batang & $\begin{array}{l}\text { Tiang persembahan } \\
\text { dan/atau tiang sudut }\end{array}$ \\
\hline 6 & Uvaria rufa Blume & Lelak & Koknaba & Annonaceae & Batang & Rangka atap \\
\hline 7 & $\begin{array}{l}\text { Arenga pinnata (Wurmb) } \\
\text { Merr. }\end{array}$ & Aren & Enau & Arecaceae & Batang & Rangka atap \\
\hline 8 & Tectona grandis L.f. & Jati & Jati & Lamiaceae & Batang & Dinding \\
\hline 9 & $\begin{array}{l}\text { Eucalyptus alba Reinw.ex } \\
\text { Blume }\end{array}$ & Kayu putih & Hau muti & Myrtaceae & Batang & Tiang sudut \\
\hline 10 & Cassia planisiliqua $\mathrm{L}$. & $\begin{array}{l}\text { Tegining } \\
\text { ganang }\end{array}$ & Kuma & Fabaceae & Batang & Tiang \\
\hline 11 & Areca catechu L. & Pinang & Puah & Arecaceae & Kulit batang & Rangka atap \\
\hline 12 & $\begin{array}{l}\text { Entada phaseoloides (L.) } \\
\text { Merr. }\end{array}$ & Gandu/bendoh & Fa'ek & Fabaceae & Batang & Pengikat \\
\hline 13 & $\begin{array}{l}\text { Bambusa multiplex } \\
\text { (Lour.) Raeusch. ex } \\
\text { Schult. \& Schult f }\end{array}$ & Bambu pagar & Bambu & Poaceae & Serat batang & Pengikat \\
\hline 14 & Calamus zoliingeri B. & Rotan & Rotan & Arecaceae & Batang & Rangka atap \\
\hline 15 & $\begin{array}{l}\text { Imperata cylindrical (L.) } \\
\text { Raeusch }\end{array}$ & Alang-alang & $\begin{array}{l}\text { Alang- } \\
\text { alang }\end{array}$ & Poaceae & Daun & Atap \\
\hline
\end{tabular}


Bagian depan rumah adat biasanya terdapat tiang persembahan yang terdiri atas kayu bercabang dan antar cabangnya dipasangkan batu datar besar. Kayu yang digunakan adalah trengguli atau trengguli wanggang. Menurut tradisi masyarakat setempat (ketiga rumah adat) tiang ini berfungsi sebagai tempat untuk menaruh batu di atasnya dan bermanfaat sebagai tempat meletakkan sesajen (hasil panen baru pada musim panen) sebelum dikonsumsi oleh masyarakat setempat.

\section{Analisis Vegetasi}

Vegetasi mempunyai peranan penting dalam menyediakan berbagai sumber daya hayati yang diperlukan oleh manusia. Vegetasi berfungsi dalam pengatur hidrologi dan juga mengatasi kekeringan. Hasil analisis vegetasi diperoleh data berupa jumlah individu, jumlah spesies, dan diameter batang. Data yang diperoleh selanjutnya dilakukan perhitungan densitas relatif (DR), frekuensi relatif (FR), luas basal area (LBA) relatif. Selanjutnya, dari hasil perhitungan tersebut, diperoleh Indeks nilai penting (INP) dari penjumlahan densitas relatif, frekuensi relatif dan luas area basal relatif setiap spesies yang ditemukan. Spesies yang paling dominan atau berkuasa adalah spesies yang memiliki indeks nilai penting tertinggi atau yang paling besar (Indriyanto 2008).

Dari hasil perhitungan Indeks Nilai Penting (Gambar 5) dapat diketahui bahwa spesies dominan pada wilayah Tunbaba adalah trengguli, sedangkan wilayah Fafinesu dan wilayah Tamkesi adalah kayu merah. Hal ini menunjukkan bahwa walaupun kayu merah merupakan unsur penting dalam bangunan rumah adat Etnis Dawan di Kabupaten Timor Tengah Utara, keberadaannya sudah sangat berkurang. Menurut para informan di Wilayah Kecamatan Miomaffo Timur, hal ini disebabkan tidak adanya kesadaran masyarakat dalam melakukan sistem tebang-tanam ganti dan tidak adanya hutan adat seperti yang ada di dua Kecamatan lainnya.

Kayu merah memiliki penyebaran dari Burma selatan melalui Semenanjung Thailand, Vietnam, Malaysia, Indonesia, Filipina, Papua Nugini, Kepulauan Andaman India, Solomon, dan Carolina. Di Indonesia meliputi Jawa, Sulawesi, Maluku, Bali, Nusa Tenggara Timur, Nusa Tenggara Barat, dan Papua. Berdasarkan penelitian Yuskianti et al. (2017) bentuk biji berduri ditemukan di pulau Sumbawa, Nusa Tenggara Barat. Sulistyawati dan Widyatmoko (2017) mengungkapkan adanya pergerakan gen dan kedekatan genetik antara populasi Seram dengan populasi Pulau Timor dibandingkan dengan populasi dari Pulau Flores.

Kayu merah memiliki kandungan pigmen berwarna merah yaitu narrin, santalin, angolesin. Batang kayunya memiliki aroma harum yang khas. Selain itu, tumbuhan ini mengandung senyawa terpen, fenol, flavon, isoflavon, tannin dan lignin (Lestari dan Satria 2017). Oleh karena kandungan kimianya, spesies ini resisten terhadap serangga perusak kayu sehingga banyak digunakan untuk bahan furniture. Akar kayu merah dapat digunakan sebagai obat tradisional untuk pengobatan sifilis dan getah batangnya untuk pengobatan kanker. Lebih lanjut, kulit kayu merah juga bisa digunakan sebagai obat anti diare, antimalaria, meringankan penyakit kandung kemih, edema, ganguan hati, dan sakit kepala.

Trengguli/tengguli/kayu raja (Cassia fistula L.) merupakan salah satu spesies deciduous berhabitus pohon. Spesies ini berasal dari India dan Sri Lanka tetapi tersebar merata di daerah tropis saat ini. Penyebaran tumbuhan ini direpresentasikan dengan kegunaannya sebagai tumbuhan obat yang berharga. Spesies ini memiliki potensi sebagai hepatoprotektif, antiinflamasi, antitusif, antijamur dan antibakteri. Spesies ini kaya senyawa tanin, flavanoid dan glikosida (Danish et al. 2011).

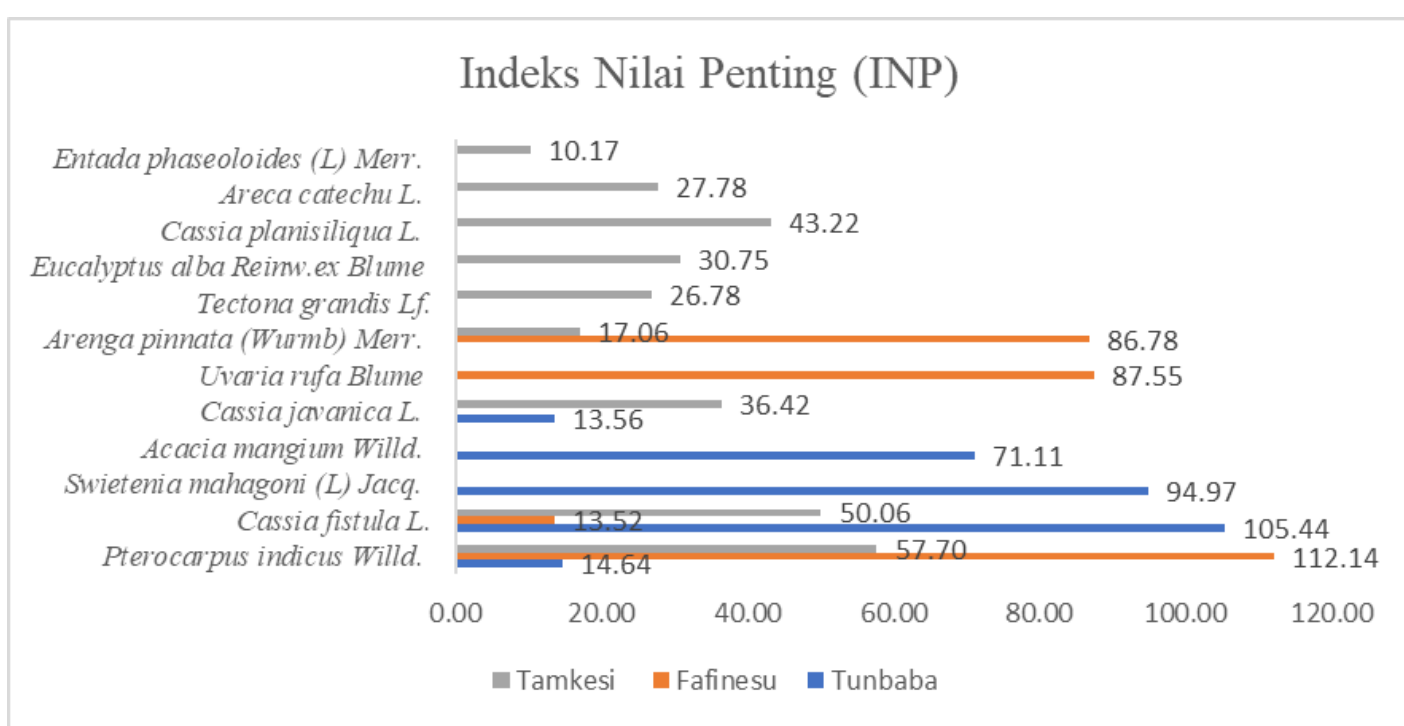

Gambar 5. Indeks Nilai Penting spesies tumbuhan bahan bangunan rumah adat Etnis Timor di Kabupaten Timor Tengah Utara 
Spesies yang memiliki indeks nilai penting tinggi juga sebanding dengan hasil persentase tertinggi keberadaan spesies tersebut sebagai tumbuhan penting di rumah adat Etnis Timor di Kabupaten Timor Tengah Utara. Walaupun demikian, indeks nilai penting setiap wilayah yang berbeda menunjukkan adanya pengaruh lingkungan seperti ketinggian tempat, tingkat kesuburan tanah, suhu, dan faktor fisik lainnya serta pengaruh campur tangan manusia sebagai pembatas pertumbuhan spesies-spesies tumbuhan tersebut.

\section{SIMPULAN}

Masyarakat etnis Dawan di Kabupaten Timor Tengah Utara memiliki hubungan yang erat antara budaya dan alam lingkungannya dengan mengenali dan memanfaatkan 15 jenis tumbuhan yang termasuk ke dalam tujuh famili sebagai bahan bangunan rumah tradisional. Ketersediaan spesies tumbuhan yang digunakan sebagai bahan bangunan rumah tradisional sangat bervariasi dan sudah sangat menurun drastis. Kecenderungan memanfaatkan tumbuhan untuk kepentingan budaya spiritual diutamakan sehingga keseimbangan dengan sumber daya alam yang ada di lingkungannya menjadi terjaga.

\section{DAFTAR PUSTAKA}

Ahmed JU. 2010. Development Vision of North-East India. New Delhi: Concept Publishing Company (P) TLD.

Atok AR, Hikmat A, Zuhud EAM. 2010. Etnobotani Masyarakat Suku Bunaq (Studi Kasus di Desa Dirun, Kecamatan Lamaknen Kabupaten Belu, Provinsi Nusa Tenggara Timur). Media Konservasi. 15 (1): $36-42$.

Awalia N, Syamswisna, Marlina R. 2014. Etnobotani tumbuhan pewarna di Menyuke dan implementasinya dalam pembuatan animasi slide show manfaat biodiversitas. Artikel Penelitian. Pontianak: Universitas Tanjung Pura.

Backers CA, Brink jr AVD. 1968. Flora of Java. Groningen: Noordhoff.

Cunningham BA. 2001. Applied Ethnobotany People, Wild Plant Use, and Conservation. London: Earthscan Publications Ltd.

Danish M, Singh P, Mishra G, Srivastava S, Jha KK, Khosa RL. 2011. Cassia fistula Linn. (Amulthus)An important medicinal plant: A Review of its traditional uses, phytochemistry and pharmacological propertie. J. Nat. Prod. Plant Resource. 1 (1): 101-118.

Fanggidae LW. 2014. Bentuk \& Struktur Rumah Tradisional Etnis Tetun Di Kabupaten Belu, Nusa Tenggara Timur. Denpasar: LPPM UNMAS.

Indriyanto. 2008. Ekologi Hutan. Jakarta: PT Bumi Aksara .
Integrated Taxonomic Information System (ITIS). http://www.itis.gov

Irsyad MN, Jumari, Murningsih. 2013. Studi etnobotani masyarakat Desa Sukolilo kawasan pegunungan kendeng Pati Jawa Tengah. Bioma. 15(1): 27-34.

Jumari, Setiadi D, Purwanto Y, Guhardja E. 2012. Pengetahuan lokal Masyarakat Samin tentang keanekaragaman tumbuhan dan pengelolaanya. Media Konservasi. 17(2): $71-78$

Karwur FF, Saekoko YF, Tauho KD. 2016. Ume Kbubu di Sepanjang Dusun II. Di dalam Ranimpi YY, editor. Binaus Wajah Pedesaan Timor di Abad XXI. Salatiga: Fakultas Ilmu Kesehatan UKSW.

Kuswantoro F, Lugrayasa IN, Sujarwo W. 2018. Studi ekologi kuantitatif hutan pilan sebagai dasar pengembangan Kebun Raya Gianyar. Jurnal Ilmu Kehutanan. 12 (2):184-195

Lanoeroe S, Kesaulija EM, Rahawarin YY. 2005. Pemanfaatan jenis tumbuhan berkayu sebagai bahan baku perahu tradisional oleh Suku Yachai di Kabupaten Mappi. Biodiversitas. 6(3): 212-216.

Lestari DW, Satria Y. 2017. Pemanfaatan kulit kayu angsana (Pterocarpus indicus) sebagai sumber zat warna alam pada pewarnaan kain batik sutera. Dinamika Kerjinan dan Batik. 34(1):35-42.

Martin GJ. 1995. Ethnobotany: A Methods Manual. London: Chapman and Hall.

Mueller-Dombois D, Ellenberg H. 1974. Aims and Methods of Vegetation Ecology. New York: John Wiley and Sons.

Nicolson M. 2001. Towards establishing ecology as a science instead of an art": the work of John T. Curtis on the plant community continuum. Webecology 2.

Pramita NH, Indriyani S, Hakim L. 2013. Etnobotani upacara Kasada masyarakat Tengger, di Desa Ngadas, Kecamatan Poncokusumo, Kabupaten Malang. Journal of Indonesian Tourism and Development Studies. 1 (2): 52-61.

Purwanto Y. 2007. Ethnobiologi. Ilmu interdisipliner, metodologi, aplikasi, dan prosedurnya dalam pengembangan Sumberdaya tumbuhan [bahan kuliah Pascasarjana]. Bogor: IPB.

Soedigdo D. 2010. Arsitektur regionalisme. Jurnal Perspektif Artitektur. 5(1): 26 - 32.

Sujarwo W, Keim AP. 2017. Ethnobotanical study of traditional building materials from the Island of Bali, Indonesia. Economic Botany. 71 (3): 224-240.

Sulistyawati P, Widyatmoko AYPBC. 2017. Keragaman genetik populasi kayu merah (Pterocarpus indicus Willd) menggunakan penanda Random Amplified Polymorphism DNA. Jurnal Pemuliaan Tanaman Hutan. 11 (1): 67-7.

Supiandi MI, Mahanal S, Zubaidah S, Julung H, Ege B, 2019. Ethnobotany of traditional medicinal plants used by Dayak Desa Community in Sintang, West Kalimantan, Indonesia. Biodiversitas. 20 (5): 12641270 
Tjitrosoepomo G. 1988. Taksonomi Tumbuhan (Spermatophyta). Yogyakarta: Gadjah Mada University Press.

United State Department Agriculture (USDA) Plants Database. https://plants.sc.egov.usda.gov>java

Walujo EB. 2011. Sumbangan ilmu etnobotani dalam memfasilitasi hubungan manusia dengan tumbuhan dan lingkungannya. Jurnal Biologi Indonesia. 7 (2): 375-391.

Wiryono. 2012. Ekologi Hutan. Bengkulu: UNIB Press.
Yuskianti V, Ismail B, Yuliah. 2017. Eksplorasi materi genetik kayu merah (Pterocarpus indicus Willd) di Pulau Sumbawa, Nusa Tenggara Barat. Prosiding SNPBS (Seminar Nasional Pendidikan Biologi Saintek) ke-2. 284-291.

Zulharman, Aryanti NA. 2016. Etnobotani tumbuhan penghasil bahan bangunan, kerajinan dan rumah adat masyarakat Suku Sambori Kabupaten Bima NTB. Seminar Nasional dan Gelar Produk (SENASPRO). Malang: UMM. 